\title{
HUBUNGAN BAURAN PEMASARAN JASA PELAYANAN KEPERAWATAN DENGAN LOYALITAS PASIEN
}

\author{
CORELLATION BETWEEN MARKETING MIX OF NURSING CARE WITH PATIENT LOYALTY
}

\author{
Nova Rita
}

Fakultas Keperawatan, Universitas Andalas, Padang

E-mail: afifhamdalah@gmail.com

\begin{abstract}
High public interest to go abroad for treatment need to be a particular concern for hospitals in the country. The hospital is not only able to create berkelualitas services but also need to create loyalty to the patient. Loyalty will be created if any implementation of nursing services mix well done. This study aims to determine the relationship of nursing mix shipping services with patient loyalty. This type of survey research with cross sectional analytic study with a sample of 68 people. The way to get the sample with stratified proportional is random sampling. The research result was analyzed by using chi square and logistic regression test. The result of research showed that there is a significant relationship between the marketing mix with nursing service ( product, place, price, promotion, people, and process, as well as physical evidence) with the patient loyalty in which score $p>0,05$. A conclusion of the research is simplified that there is a relationship between the marketing mix with hospital service for the patient loyalty. The relationship could be seen at people variable and health insurance with patient loyalty. The development division for service and marketing at hospital is necessary to apply the specific cost as to promote the old patient and the qualified service of nursing. The other major focus want to develop the healthy service of nursing treatment, also provide the patients' satisfaction, thus it make patients' loyalty on the installation of hospitality of Ambun Pag.
\end{abstract}

Keywords: mixed, marketing, loyalty, patients

\section{PENDAHULUAN}

Persaingan rumah sakit dalam memperebutkan pasien sebagai konsumen pengguna jasa pelayanan kesehatan, tidak hanya terjadi antar rumah sakit yang beranggotaan BPJS. Rumah sakit milik swasta maupun pemerintah juga harus bersaing dalam memperebutkan minat pasien yang tidak terdaftar sebagai anggota BPJS, sebab lebih dari separuh masyarakat Indonesia masih belum terdaftar sebagai anggota BPJS (Tim Penyusun Bahan Sosialisasi dan Advokasi JKN, 2013). Ini berarti sekitar 50\% masyarakat Indonesia masih bebas untuk menentukan pilihan rumah sakit mana yang akan mereka gunakan. Keadaan ini juga menjadi peluang bagi rumah sakit untuk menarik minat pasien.

Loyalitas merupakan suatu kesetian yang ditunjukan oleh konsumen dengan melakukan pembelian secara teratur dalam jangka waktu yang panjang melalui serangkaian keputusan yang diambil konsumen (Hasan, 2013). Menurut Griffin (2007), loyalitas konsumen adalah pelanggan yang tidak hanya membeli ulang suatu barang atau jasa, tetapi juga mempunyai komitmen dan sikap posif terhadap perusahaan jasa, sehingga juga merekomendasikan perusahaan jasa tersebut kepada pihak lain.

Loyalitas tidak hanya timbul dari rasa puas pasien terhadap kualitas pelayanan kesehatan rumah sakit. Loyalitas juga dapat tercipta dari sistem pemasaran (marketing) yang baik dari suatu rumah sakit (Hartono, 2010). Hal ini dikarenakan marketing merupakan sebuah konsep ilmu dalam strategi bisnis yang bertujuan untuk mencapai kepuasan yang berkelanjutan bagi stakeholder (Hasan, 2013). Menurut kotler (2005), marketing merupakan proses 
mengidentifikasi, menciptakan dan mengkomunikasikan nilai serta memelihara hubungan yang memuaskan konsumen untuk memaksimalkan keuntungan bagi perusahaan.

Bauran pemasaran yang digunakan oleh rumah sakit, dapat dijadikan alat pemasaran yang memudahkan rumah sakit dalam mencapai tujuan pemasaran. Hal ini menurut Hartono (2010), disebabkan oleh karena komponen-komponen dalam bauran pemasaran jasa diantaranya produk (product), tempat (place), harga (price), promosi (promotion), orang yang terkait dalam pelayanan (people), proses jasa (proccess) dan bukti fisik (physical evidence) dapat berperan penting dalam membantu konsumen dalam hal ini pasien untuk memahami dan mengevaluasi jasa rumah sakit yang bersifat nyata (intangible).

Menurut Huber (2006) dalam Suprianto (2011), sumberdaya yang sangat berperan dalam meningkatkan kualitas jasa pelayanan dirumah sakit adalah perawat, hal ini dikarenakan perawat merupakan kelompok tenaga kerja yang terbesar dalam memberikan pelayanan kesehatan secara berkesinambungan selama 24 jam dalam 1 hari dan 7 hari dalam 1 minggu. Hal ini didukung dengan hasil penelitian Potter \& Perry (2005) yang dilakukan dibeberapa rumah sakit, dimana hasil penelitian tersebut menunjukkan bahwa $70-80 \%$ tenaga kesehatan yang ada dirumah sakit adalah tenaga keperawatan.

Besarnya pengaruh pelayanan keperawatan dalam meningkatkan kualitas pelayanan kesehatan dirumah sakit. Keadaan ini menyebabkan pelayanan keperawatan dijadikan sebagai salah satu indikator dalam mengukur kualitas pelayanan kesehatan rumah sakit (Sumijatun, 2008). Menurut Potter \& Perry (2009), menyatakan bahwa keberhasilan kualitas pelayanan kesehatan dipengaruhi oleh partisipasi perawat dalam memberikan pelayanan keperawatan yang berkualitas kepada pasien.

Studi pendahuluan tentang loyalitas pasien yang dilakukan di instalasi rawat inap ambun pagi RSUP Dr. M. Djamil Padang terhadap 7 orang pasien yang diwawancarai, didapatkan 5 dari 7 orang pasien yang diwawancarai menyatakan sangat loyal terhadap instalasi rawat inap ambun pagi dan mereka juga akan melakukan kunjungan ulang bila suatu waktu kembali membutuhkan pelayanan kesehatan. Pada studi pendahuluan tentang bauran jasa pelayanan keperawatan yang juga dilakukan dengan wawancara terhadap 7 orang pasien, didapatkan 5 orang pasien menyatakan bahwa instalasi rawat inap ambun pagi memiliki kualitas pelayanan yang baik, team kesehatan yang lengkap, ramah dan penuh emphaty, harganya yang terjangkau, lokasi strategis yang terletak di pusat kota, ruangan yang bersih dan nyaman serta memiliki informasi yang mudah didapat. Fenomena yang ditemui peneliti saat melakukan studi pendahuluan di instalasi rawat inap ambun pagi adalah banyaknya daftar antrian pasien untuk mendapatkan pelayanan kesehatan.

Instalasi rawat inap ambun pagi yang memiliki kualitas pelayanan kelas I, VIP dan super VIP juga mendapat ancaman dalam menarik minat pasien dari rumah sakit swasta yang berada dalam 
negeri maupun luar negeri. Hal ini terlihat dari banyaknya rumah sakit swasta yang juga memiliki kualitas pelayanan yang sama dengan instalasi rawat inap ambun pagi, selain itu tingginya minat masyarakat Sumatera Barat untuk mendapatkan pelayanan kesehatan ke Malaka dan Singapura juga menjadi ancaman bagi instalasi rawat inap ambun pagi. Keadaan ini perlu mendapat perhatian yang lebih dari bagian pengembangan pelayanan kesehatan untuk instalasi rawat inap ambun pagi. Penelitian ini bertujuan untuk mengetahui hubungan bauran pemasaran jasa pelayanan keperawatan dengan loyalitas pasien di instalasi rawat inap ambun pagi RSUP Dr.M.Djamil Padang.

\section{METODE}

Jenis penelitian ini adalah penelitian survey analitik dengan rancangan cross sectional study, dimana penelitian ini dilakukan dengan waktu pengukuran data variabel independen, variabel dependen dan variabel counfonding hanya satu kali pada satu saat (Arikunto, 2010). Penelitian ini dilakukan di instalasi rawat inap ambun pagi RSUP Dr.M.Djamil Padang. Penelitian dilakukan mulai bulan Februari sampai dengan bulan Juli tahun 2014. Waktu pengumpulan data pada penelitian ini selama 4 (empat) minggu yaitu dari tanggal 19 Mei sampai dengan 14 Juni 2014.

\section{HASIL DAN PEMBAHASAN}

Pada hasil analisis univariat diperoleh data tentang distribusi frekuensi dari karakteristik pasien (umur, jenis kelamin, tingkat pendidikan dan asuransi kesehatan). Pasien yang menjalani perawatan di instalasi rawat inap ambun pagi RSUP Dr. M. Djamil Padang berumur dewasa menengah $(64,7 \%)$, berjenis kelamin laki - laki $(51,5 \%)$, berpendidikan tinggi $(89,7 \%)$ dan memiliki asuransi kesehatan $(67,6 \%)$. Penelitian yang dilakukan oleh Yori (2011), mendapatkan hasil bahwa distribusi frekuensi dari karakteristik pasien tidak jauh berbeda dengan hasil pada penelitian ini. Yori (2011) mendapatkan lebih dari separuh pasien berumur dewasa menengah $(65,3 \%)$ dan berjenis kelamin laki - laki (55,5\%), untuk tingkat pendidikan sebagian besar pasien dengan pendidikan tinggi (85,7\%) serta lebih dari separuh pasien memiliki asuransi kesehatan (65,3\%). Penelitian yang dilakukan oleh Indriani (2008), juga memperlihatkan hasil bahwa lebih dari separuh pasien berumur dewasa menengah $(63,7 \%)$ dan berjenis kelamin laki - laki $(58,4 \%)$, untuk tingkat pendidikan sebagian besar pasien dengan pendidikan tinggi $(81,6 \%)$ serta lebih dari separuh pasien memiliki asuransi kesehatan $(66,6 \%)$.

Hasil analisis unvariat pada penelitian ini yang mendapatkan lebih dari separuh $(64,7 \%)$ pasien berumur dewasa menengah (36 - 65 tahun). Seseorang dengan umur dewasa menengah (36 65 tahun) sudah dapat menentukan dan memutuskan dengan bijak tentang keputusan yang mereka ambil karena seseorang dengan umur dewasa menengah ini sudah memiliki kematangan dalam berpikir dan dapat menganalisis keadaan dengan menggunakan rasional. Adanya hasil penelitian yang menunjukan bahwa lebih dari 
separuh pasien berumur dewasa menengah yang menjadi sampel pada penelitian. Ini berarti pasien sudah dapat dengan baik memberikan penilaian terhadap bauran pemasaran jasa pelayanan keperawatan dan rasa loyalitas pasien terhadap instalasi rawat inap ambun pagi RSUP Dr. M. Djamil Padang.

Lebih dari separuh $(51,5 \%)$ pasien berjenis kelamin laki - laki. Jenis kelamin berhubungan dengan gender, dalam memberikan penilaian dan pengambilan keputusan pria lebih mengutamakan rasional bila dibandingkan dengan wanita karena wanita dalam memberikan penilaian selalu ada unsur perasaan. Ini berarti bila dihubungkan dengan hasil penelitian maka dapat dikatakan bahwa penilaian yang diberikan oleh pasien terhadap bauran dan loyalitas sudah memberikan penilaian secara benar tanpa ada unsur perasaan. Tingkat pendidikan pasien juga dapat mempengaruhi persepsi pasien dalam memberikan penilaian terhadap jasa pelayanan. Seseorang dengan pendidikan tinggi akan lebih selektif dalam memberikan suatu penilaian dan mayoritas seseorang dengan tingkat pendidikan tinggi maka daya rasionalnya juga akan lebih luas, sehingga ia akan lebih mampu menganalisa lebih mendalam sebelum memberikan suatu penilaian.

Hasil penelitian terhadap analisis univariat tentang tingkat pendidikan pasien, didapatkan lebih dari separuh $(89,7 \%)$ pasien yang menjalani perawatan di instalasi rawat inap ambun pagi RSUP Dr. M. Djamil Padang memiliki tingkat pendidikan yang tinggi. Ini berarti dalam memberikan penilaian terhadap bauran pemasaran jasa pelayanan keperawatan serta dalam memutuskan rasa loyalitas pasien terhadap instalasi rawat inap ambun pagi RSUP Dr. M. Djamil Padang. Pasien sudah dapat memberikan penilaian secara benar karena sebelum memberikan penilaian pasien sudah melakukan pertimbangan secara selektif dengan menggunakan rasional dan ilmu pengetahuan yang ada.

Asuransi kesehatan yang merupakan bagian dari karakteristik pasien juga dapat mempengaruhi persepsi pasien dalam menentukan pilihan rumah sakit. Selain itu asuransi kesehatan juga mampu mempengaruhi rasa loyalitas pasien terhadap fasilitas kesehatan. Bila di tinjau dari segi pemasaran, rumah sakit yang memiliki kerja sama dengan asuransi kesehatan maka rumah sakit tersebut sudah melaksanakan variabel promosi dari bauran pemasaran. Hasil penelitian mendapatkan bahwa lebih dari separuh $(67,6 \%)$ pasien yang menjalani perawatan di instalasi rawat inap ambun pagi RSUP Dr. M. Djamil Padang memiliki asuransi kesehatan. Ini berarti lebih dari separuh pasien dalam memilih instalasi rawat inap ambun pagi RSUP Dr. M. Djamil Padang juga dipengaruhi oleh asuransi kesehatan yang mereka miliki. Selain itu kriteria insklusi pada penelitian ini juga membatasi bahwa pasien yang menjadi sampel dari penelitian ini adalah pasien yang sudah pernah menjalani perawatan minimal satu kali di instalasi rawat inap ambun pagi RSUP Dr. M. Djamil Padang. Keadaan ini bila dihubungkan dengan rasa loyalitas pasien, maka kembalinya pasien untuk menjalani perawatan di instala rawat inap ambun pagi RSUP Dr. M. Djamil 
Padang juga sangat dipengaruhi oleh asuransi kesehatan yang mereka miliki. Ini berarti selain asuransi kesehatan mempengaruhi keputusan pasien dalam memilih rumah sakit, asuransi kesehatan juga mampu mempengaruhi rasa loyalitas pasien terhadap rumah sakit.

Saat ini instalasi rawat inap ambun pagi RSUP Dr. M. Djamil Padang sudah melakukan kerja sama dengan asuransi kesehatan. Ini berarti instalasi rawat inap ambun pagi RSUP Dr. M. Djamil Padang sudah melaksanakan bauran pemasaran jasa pada komponen promosi. Adanya kerjasama dengan asuransi kesehatan ini yang membuat hasil penelitian menemukan lebih dari separuh $(67,6 \%)$ pasien memiliki asuransi kesehatan memilih instalasi rawat inap ambun pagi sebagai tempat pelayanan perawatan. Ini berarti loyalitas pasien terhadap instalasi rawat inap ambun pagi sangat dipengaruhi oleh asuransi kesehatan yang dimiliki pasien. Tingginya jumlah pasien yang memiliki asuransi kesehatan menjalani perawatan di instalasi rawat inap ambun pagi RSUP Dr. M. Djamil Padang. Ini bukan berarti instalasi rawat inap ambun pagi sudah memiliki sistem bauran pemasaran jasa pelayanan yang baik, karena masih ada sekitar $(32,4 \%)$ pasien yang menjalani perawatan di instalasi rawat inap ambun pagi tidak memiliki asuransi kesehatan, selain itu masih banyak lagi rumah sakit lain yang juga melakukan kerja sama dengan asuransi kesehatan. Ini perlu menjadi pertimbangan pada bagian pengembangan instalasi rawat inap ambun pagi RSUP Dr. M. Djamil Padang karena tidak semua pasien yang memiliki asuransi kesehatan akan memilih instalasi rawat inap ambun dan tidak semua masyarakat memiliki asuransi kesehatan.

Pada hasil analisis univariat didapatkan lebih dari separuh $(64,7 \%)$ pasien memiliki rasa loyalitas yang baik terhadap instalasi rawat inap ambun pagi RSUP Dr. M. Djamil Padang. Tingginya loyalitas pasien terhadap instalasi rawat inap ambun pagi, hal ini terlihat dari jawaban responden terhadap kuesioner yang ada karena lebih dari separuh $(58,8 \%)$ responden menyatakan akan kembali berkunjung ke instalasi rawat inap ambun pagi, $(55,9 \%)$ responden menyatakan akan mempromosikan instalasi rawat inap ambun pagi kepada pihak lain, (60,3\%) responden akan mengajak keluarga dan orang lain untuk menjalani perawatan di instalasi rawat inap ambun pagi, $(55,9 \%)$ responden menyatakan bahwa pelayanan yang mereka terima sesuai dengan harapan dan $(54,4 \%)$ responden menyatakan bahwa keputusan mereka memilih instalasi rawat inap ambun pagi karena sebelumnya mendapatkan informasi dari kerabat tentang keunggulan fasilitas dan pelayanan yang dimiliki instalasi rawat inap ambun pagi.

Keadaan lain yang menyebabkan tingginya loyalitas pasien terhadap instalasi rawat inap ambun pagi juga terlihat pada jawaban responden terhadap pertanyaan yang berpola negatif. Responden menyatakan tidak akan berpindah kerumah sakit lainnya bila suatu waktu kembali membutuhkan pelayanan rumah sakit $(76,4 \%)$, responden menyatakan akan merekomendasikan instalasi rawat inap ambun pagi kepada keluarga maupun orang lain $(80,8 \%)$, responden tidak akan 
menceritakan tentang keburukan dari kualitas pelayanan $(75,0 \%)$ dan responden menyatakan bahwa pelayanan yang diterima sesuai dengan tarif yang mereka bayarkan $(73,5 \%)$.

Hasil penelitian ini sama dengan penelitian yang dilakukan oleh Indriani (2008), lebih dar separuh $(63,8 \%)$ pasien memiliki rasa loyalitas. Sedangkan hasil penelitian Ika (2009), juga memperlihatkan bahwa lebih dari separuh $(65,5 \%)$ pasien loyal terhadap rumah sakit. Adanya kesamaan hasil penelitian ini dengan penelitian terkait, ini berarti adanya kesamaan kualitas pelaksanaan bauran pemasaran jasa pelayanan keperawatan yang dimiliki pada tempat penelitian.

Rasa loyalitas pasien yang baik terhadap instalasi rawat inap ambun pagi apabila dihubungkan dengan asuransi kesehatan yang dimiliki oleh pasien maka loyalitas yang ditunjukan oleh pasien bisa saja tidak termasuk kedalam dimensi loyal. Hal ini dapat disebabkan oleh keterpaksaan karena pasien memiliki asuransi kesehatan, namun bila dilihat dari model kesetiaan konsumen maka asuransi kesehatan yang dimiliki oleh pasien dapat menyebabkan pasien memiliki loyalitas premium karena dengan keterikatan yang tinggi (memiliki asuransi kesehatan) pasien juga memiliki loyalitas yang baik.

Rasa loyalitas pasien yang baik terhadap instalasi rawat inap ambun pagi tidak hanya dipengaruhi oleh asuransi kesehatan yang dimiliki oleh pasien, karena bila dilihat dari presentase pasien yang menjawab kuesioner yang berhubungan dengan loyalitas pasien maka rasa loyalitas pasien tidak hanya dipengaruhi oleh asuransi kesehatan namun juga dipengaruhi oleh faktor lain seperti pasien menjadi loyal karena pelayanan yang diberikan sesuai dengan harapan sehingga bila suatu waktu kembali membutuhkan perawatan maka pasien akan kembali berkunjung. Hal ini bila ditinjau dari perkembangan loyalitas maka termasuk pada tahap ketiga yaitu pada tahap konatif. Pada tahap konatif ini kondisi loyal mencakup komitmen yang mendalam untuk melakukan pembelian.

Cara pengukuran tentang loyalitas sampai saat ini belum ada kesepakatan namun bila dilihat dari cara pengukuran loyalitas menurut Setiawan (2011), maka hasil penelitian loyalitas ini diperoleh dari umpan balik konsumen yang dapat dikumpulkan melalui berbagai cara salah satunya adalah dengan cara survey yang dilakukan pada penelitian ini. Presentase hasil dari loyalitas juga belum ada kesepakatan, oleh karena itu pada penelitian ini peneliti menggunakan presentase dari nilai mean, jika presentase dari hasil penelitian melebihi dari nilai mean maka responden dikatakan loyal begitupun dengan sebaliknya.

Hasil penelitian yang mendapatkan lebih dari separuh pasien loyal terhadap instalasi rawat inap ambun pagi RSUP Dr. M. Djamil Padang. Ini berarti tingginya rasa loyalitas pasien akan memberikan keuntungan bagi instalasi rawat inap ambun pagi RSUP Dr. M. Djamil Padang. Keuntungan tidak hanya dilihat dari banyaknya pasien berkunjung tetapi keuntungan dapat dilihat dari segi promosi yang dilakukan oleh pasien kepada pihak lain, dengan adanya promosi yang 
dilakukan oleh pasien maka akan memberikan keuntungan berkelanjutan sekaligus menghemat biaya promosi rumah sakit terhadap jasa pelayanan.

Pada hasil analisis bivariat didapatkan presentase loyalitas pasien lebih tinggi pada pasien yang menyatakan produk yang berkualitas $(100,0 \%)$ dibandingkan dengan pasien yang menyatakan produk kurang berkualitas $(11,1 \%)$. Hasil uji statistik menunjukan nilai $p$ value $0,001(<0,05)$ maka dapat disimpulkan ada hubungan yang signifikan antara produk dengan loyalitas pasien terhadap instalasi rawat inap ambun pagi RSUP. Dr. M. Djamil Padang. Hasil penelitian ini sama dengan penelitian yang dilakukan oleh Ika (2009), yang juga menemukan adanya hubungan yang signifikan antara produk dengan loyalitas pasien. Penelitian dari Lita (1999), mendapatkan bahwa produk merupakan salah satu faktor yang dipertimbangkan pasien dalam memilih rumah sakit. Kuntjara (2007), pada penelitiannya mendapatkan pengaruh yang positif antara produk dengan loyalitas pasien.

Adanya hubungan yang signifikan antara produk dengan loyalitas pasien, ini berarti tingginya loyalitas pasien terhadap produk yang ada di instalasi rawat inap ambun pagi dapat disebabkan karena instalasi rawat inap ambun pagi memiliki produk berkualitas. Keadaan ini dibuktikan dengan hasil uji analisis univariat bahwa lebih dari separuh pasien menyatakan produk berkualitas $(60,3 \%)$. Secara terperinci penyebab tingginya loyalitas pasien terhadap produk berkualitas, dapat dilihat dari jawaban responden terhadap kuesioner penelitian yang mana lebih dari separuh $(55,9 \%)$ responden menyatakan bahwa perawat selalu meminta persetujuan pasien dan keluarga sebelum melakukan tindakan, $(60,3 \%)$ responden menyatakan perawat dapat melakukan tindakan keperawatan secara terampil dan selalu menjaga privasi pasien, $(60,3 \%)$ responden menyatakan bahwa perawat selalu menjelaskan kepada pasien tentang perawat yang selanjutnya merawat pasien, $(55,9 \%)$ responden menyatakan bahwa perawat selalu menjelaskan tentang makanan yang boleh dan tidak boleh dikonsumsi oleh pasien dan $(55,9 \%)$ responden juga menyatakan bahwa secara keseluruhan menyukai pelayanan yang diberikan oleh perawat di instalasi rawat inap ambun pagi. Menjelaskan dan meminta persetujuan pasien atau keluarga pasien sebelum melakukan tindakan merupakan suatu tindakan untuk menghargai harkat dan martabat pasien sebagai manusia. Selain itu dengan meminta persetujuan sebelum melakukan tindakan, bila ditinjau dari segi pasien maka merupakan hak pasien untuk mendapatkan penjelasan namun bila ditinjau dari segi perawat merupakan kewajiban perawat untuk memberikan informasi tentang tindakan yang akan dilakukan kepada pasien. Adanya persetujuan dari pasien ini berarti adanya inform concent atau kekuatan bagi perawat bila terjadi sesuatu diluar keinginan atau adanya dugaan mal praktek dari tindakan yang telah dilakukan. Tindakan keperawatan dengan terampil merupakan salah satu dari ciri - ciri perawat yang profesional. Tindakan yang tepat, cepat dan sesuai dengan prosedur tindakan akan memberikan nilai tersendiri bagi pasien terhadap perawat. Pasien 
akan menjadi lebih percaya dari tindakan yang dilakukan karena tindakan yang dilakukan dapat mengurangi keluhan pasien sehingga harapan pasien dapat terpenuhi. Harapan yang sesuai dengan kenyataan akan menciptakan rasa loyal pada diri pasien. Loyalitas yang ada juga dapat menciptakan komitmen pada diri pasien untuk melakukan kunjungan ulang bila suatu saat kembali membutuhkan dan bahkan merekomendasikan rumah sakit kepada pihak lain. Menjelaskan kepada pasien atau keluarga setiap pergantian dinas tentang siapa perawat yang akan melakukan perawatan selanjutnya kepada pasien merupakan tindakan yang harus dilakukan oleh perawat. $\mathrm{Hal}$ ini bertujuan untuk menghilangkan ketidaktahuan pasien terhadap petugas apabila pasien memerlukan bantuan. Menjelaskan makanan dan minuman yang boleh dikomsumsi atau tidak boleh boleh dikonsumsi oleh pasien merupakan salah satu tindakan dari asuhan keperawatan yang diberikan oleh perawat kepada pasien walaupun dalam pelaksanaan adanya kolaborasi dengan bagian gizi. Pasien yang mengetahaui makanan dan minuman yang boleh dikonsumsi atau tidak dapat menambah pengetahuan pasien tentang diet yang harus dilakukan dalam proses penyembuhan penyakitnya, sehingga bila pasien sudah pulang maka pasien dapat melanjutkan diet makanan tersebut dirumah dengan demikian proses pemulihan setelah pulang dari rumah sakit dapat berlanjut.

Tabel 1 Bauran Pemasaran Jasa Pelayanan Keperawatan

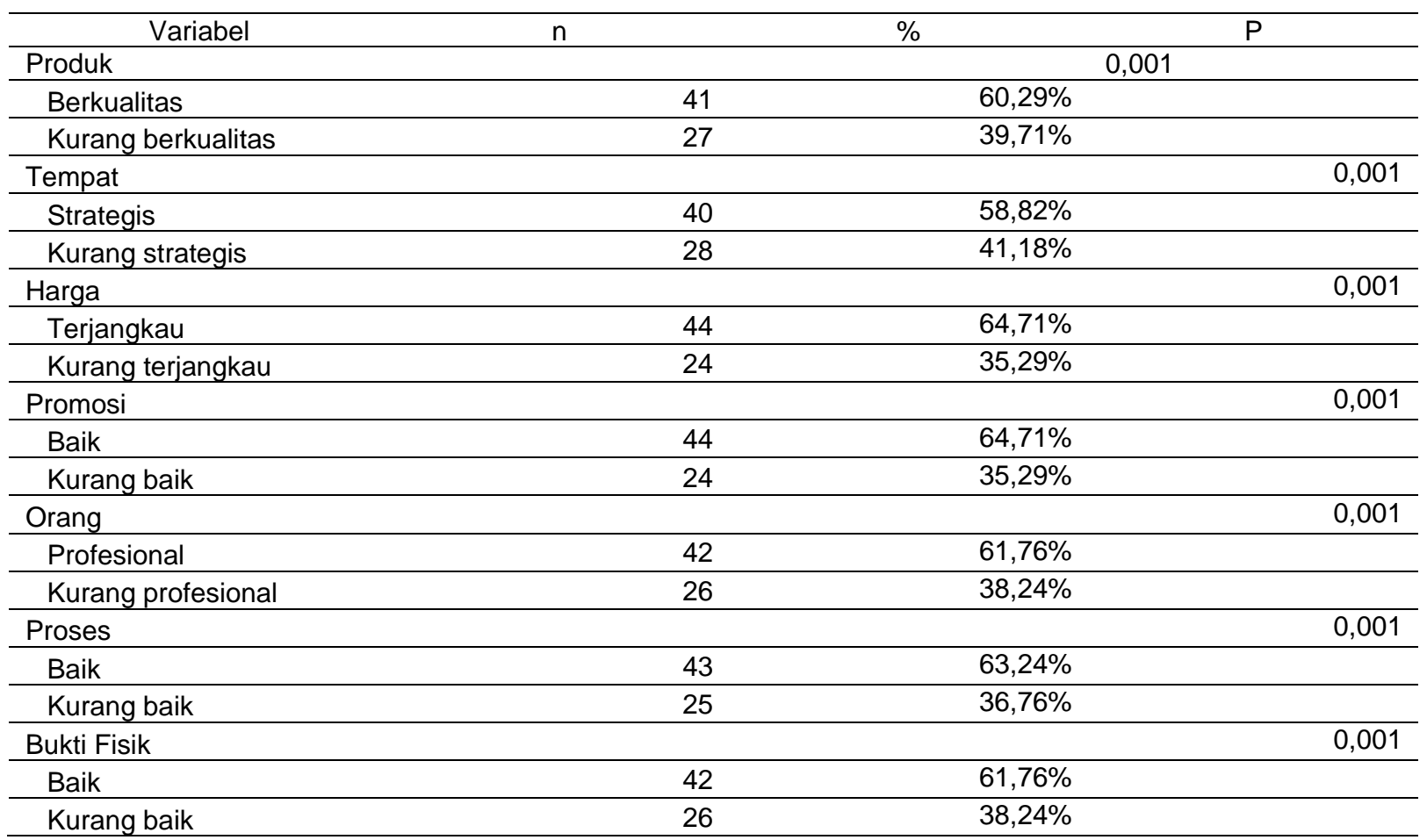

Produk berkualitas dapat diciptakan dengan sumber daya manusia yang profesional, sarana dan prasarana yang memadai. Hal ini perlu menjadi perhatian bagi rumah sakit terutama pada bagian pengembangan. Rumah sakit yang memiliki sumber daya manusia yang profesional namun tidak dilengkapi dengan sarana dan prasarana yang memadai maka tidak akan dapat menciptakan 
produk berkualitas. Begitupun sebaliknya, rumah sakit yang memiliki sarana dan prasarana yang memadai namun tidak diikuti dengan sumber daya manusia yang profesional juga tidak akan dapat menciptakan produk berkualitas. Jadi dalam menciptakan produk berkualitas diperlukan keseimbangan antara sumber daya manusia yang profesional dengan sarana dan prasarana yang memadai. Hal ini sudah dimiliki oleh instalasi rawat inap RSUP Dr. M. Djamil Padang sehingga pada hasil penelitian ini ditemukan adanya hubungan yang signifikan antara produk dengan loyalitas pasien karena lebih dari separuh pasien menyatakan produk di instalasi rawat inap ambun pagi berkualitas.

Pada hasil analisis bivariat didapatkan presentase loyalitas pasien lebih tinggi pada pasien yang menyatakan tempat strategis $(100,0 \%)$ dibandingkan dengan pasien yang menyatakan tempat kurang strategis (14,3\%). Hasil uji statistik menunjukan nilai $p$ value $0,001(<0,05)$ maka dapat disimpulkan ada hubungan yang signifikan antara tempat dengan loyalitas pasien terhadap instalasi rawat inap ambun pagi RSUP. Dr. M. Djamil Padang. Penelitian ini sama dengan penelitian yang dilakukan Indriani (2008), bahwa tempat yang strategis dari rumah sakit berhubungan signifikan dengan loyalitas pasien. Hasil penelitian Ika (2009), juga menemukan presentase loyalitas lebih tinggi pada tempat strategis dan juga menemukan adanya hubungan signifikan antara tempat dengan loyalitas pasien. Sutomo (2009), mendapatkan pengaruh positif bauran pemasaran jasa dalam hai ini adalah tempat secara parsial terhadap hasil penjualan jasa hotel berbintang di Daerah Istimewa Jogjakarta. Ini berarti rumah sakit yang memilliki tempat strategis yang setara dengan tempat hotel berbintang mampu menciptakan loyalitas pasien terhadap rumah sakit. Hasil penelitian ini bila dihubungkan dengan hasil penelitian yang dilakukan oleh Sutomo (2009), dapat dlihat bahwa tempat yang dimiliki instalasi rawat inap ambun pagi RSUP Dr. M. Djamil Padang memiliki kesamaan dengan tempat pada hotel berbintang. Letak instalasi ambun pagi dipusat kota dengan transportasi yang mudah didapat, memiliki fasilitas parkir, ruangan tunggu yang nyaman dengan fasilitas perawatan kelas, VIP dan super VIP serta dilengkapi sumber daya manusia yang profesional, sarana dan prasarana yang memadai. Tingginya presentase loyalitas pasien terhadap tempat strategis pada instalasi rawat inap ambun pagi, bila dilihat dari jawaban responden terhadap kuesioner penelitian. Hal ini dapat disebabkan oleh karena lebih dari separuh (60.3\%) responden menyatakan bahwa instalasi rawat inap ambun pagi bila dihubungkan dengan daerah yang rawan bencana gempa maka kekuatan gedung sudah cukup kuat, $(61,8 \%)$ responden menyatakan instalasi rawat inap ambun pagi memiliki tempat parkir khusus sehingga tidak mengalami kesulitan untuk parkir kendaraan dan $(52,9 \%)$ responden juga menyatakan bahwa instalasi rawat inap ambun pagi memiliki situasi lingkungan yang aman. Sedangkan untuk pertanyaan tentang lokasi instalasi rawat inap ambun pagi bila dihubungkan fasilitas umum dan pertanyaan tentang pencahayaan ruangan maka 
respoden menyatakan tempat kurang baik $(50,0 \%)$ dan tempat baik $(50,0 \%)$. Ini berarti jawaban responden untuk kedua pertanyaan berimbang. Tempat strategis yang dimiliki oleh rumah sakit merupakan satu keuntungan karena konsumen yang sakit dalam hal ini pasien, akan mencari rumah sakit yang terdekat dengan transportasi yang mudah didapat. Tempat ini dimiliki oleh instalasi rawat inap ambun pagi RSUP Dr. M. Djamil Padang, dimana terletak dipusat kota, transportasi yang mudah didapat dan didukung oleh sarana dan prasarana yang memadai seperti alur lokasi yang jelas, tempat parkir, keamanan yang terjamin dan penunjang lainnya. Kelebihan pada tempat yang dimiliki instalasi rawat inap ambun pagi mampu menciptakan loyalitas pasien.

Pada hasil analisis bivariat didapatkan semua pasien $(100,0 \%)$ yang menyatakan harga terjangkau menjadi loyal. Begitupun sebaliknya, semua pasien $(100,0 \%)$ yang menyatakan harga tidak terjangkau menjadi tidak loyal. Hasil uji statistik menunjukan nilai $p$ value $0,001(<0,05)$ maka dapat disimpulkan ada hubungan yang signifikan antara harga dengan loyalitas pasien terhadap instalasi rawat inap ambun pagi RSUP. Dr. M. Djamil Padang. Hasil penelitian ini sama dengan penelitian yang dilakukan oleh Yori (2011), hasil penelitian menemukan adanya hubungan yang signifikan antara harga dengan loyalitas pasien sehingga harga yang terjangkau akan menimbulkan keinginan berkunjung ulang bila suatu waktu pasien kembali membutuhkan. Hasil penelitian yang dilakukan Yuristin (2011), juga menemukan hubungan yang signifikan antara harga dengan keinginan berkunjung ulang. Hubungan positif juga terlihat dari pengaruh kebijakan harga dari bauran pemasaran jasa rumah sakit terhadap loyalitas pasien.

Adanya presentase yang sama antara rasa loyal dan rasa tidak loyal pasien terhadap harga terjangkau (100,0\% : 100,0\%). Hal ini bila dilihat dari analisis statistik dapat dipengaruhi oleh asuransi kesehatan yang dimiliki oleh pasien karena lebih dari separuh $(67,6 \%)$ pasien yang menjalani perawatan di instalasi rawat inap ambun pagi memiliki asuransi kesehatan. Bila keadaan ini dihubungkan dengan harga di instalasi rawat inap ambun pagi, harga menjadi tidak masalah bagi pasien karena harga yang akan dibayarkan oleh pasien sudah ditanggung oleh asuransi kesehatan. Harga akan menjadi masalah bila pasien tidak memiliki asuransi kesehatan karena pasien akan langsung membayar tarif yang ada. Hal ini menyebabkan pasien akan memperbandingkan kualitas pelayanan yang diterima dengan harga yang dibayarkan. Apabila harga yang dibayarkan tidak sesuai dengan harapan terhadap kualitas pelayanan yang diterima maka akan mengurangi bahkan akan pasien menjadi tidak loyal. Keadaan ini dibuktikan pada hasil uji bivariat dimana pasien yang menyatakan harga tidak terjangkau menjadi tidak loyal terhadap instalasi rawat inap ambun pagi. Adanya hubungan yang signifikan antara harga dengan loyalitas pasien, dengan nilai $p$ value $0,001(<0,05)$. Hal ini bila dilihat dari jawaban responden terhadap kuesioner penelitian, keadaan ini dapat disebabkan oleh karena lebih dari separuh perawat di instalasi rawat 
inap ambun pagi sudah memberikan informasi yang jelas tentang tarif yang ada $(58,8 \%)$, tarif yang tergolong murah bila dibandingkan dengan rumah sakit lainnya $(51,5 \%)$, cara pembayaran yang mudah dan cepat $(57,4 \%)$ sehingga pasien atau keluarga pasien tidak menunggu lebih lama dalam proses pembayaran, tarif yang sesuai dengan pelayanan yang diberikan $(64,7 \%)$ sehingga pasien merasa puas terhadap jasa pelayanan yang diterima dan adanya keseimbangan pelayanan yang diterima dengan tarif yang dibayarkan $(63,2 \%)$. Keadaan inilah yang menyebabkan adanya hubungan yang signfikan antara price dengan loyalitas pasien.

Instalasi rawat inap ambun pagi RSUP Dr. M. Djamil Padang yang merupakan rumah sakit milik pemerintah tentunya memiliki tarif pelayanan yang lebih murah bila dibandingkan dengan rumah sakit milik swasta. Keadaan ini memberi nilai tersendiri bagi instalasi rawat inap ambun pagi dalam menarik minat pasien, selain itu instalasi rawat inap ambun pagi juga mempunyai kerja sama dengan asuransi kesehatan untuk mempromosikan instalasi rawat inap ambun pagi kepada konsumen yang memiliki asuransi kesehatan. Tarif yang murah dan adanya kerja sama dengan asuransi kesehatan akan mampu membuat instalasi rawat inap ambun pagi untuk menarik minat konsumen untuk menggunakan jasa pelayanan di instalasi rawat inap ambun pagi. Ini dibuktikan dengan banyaknya daftar antrian pasien untuk mendapatkan pelayanan kesehatan di instalasi rawat inap ambun pagi RSUP Dr. M. Djamil Padang.
Pada hasil analisis bivariat didapatkan presentase loyalitas pasien $(100,0 \%)$ pada pasien yang menyatakan promosi baik sedangkan presentase loyalitas pasien yang menyatakan promosi kurang baik (0\%). Ini berarti pasien yang menyatakan promosi kurang baik $(100,0 \%)$ tidak loyal terhadap instalasi rawat inap ambun pagi. Hasil uji statistik menunjukan nilai $p$ value $0,001(<0,05)$ maka dapat disimpulkan ada hubungan yang signifikan antara promosi dengan loyalitas pasien terhadap instalasi rawat inap ambun pagi RSUP. Dr. M. Djamil Padang.

Hasil penelitian ini sama dengan penelitian yang dilakukan oleh Ika (2009), adanya hubungan signifikan antara promosi yang baik dengan loyalitas pasien. Lebih lanjut penelitian yang dilakukan Ika (2009), juga menemukan bahwa promosi merupakan salah satu faktor yang dipertimbangkan oleh pasien dalam memilih rumah sakit. Ini berarti promosi rumah sakit yang baik dapat menarik minat konsumen untuk menggunakan rumah sakit sebagai fasilitas kesehatan. Adanya presentase yang sama loyalitas pasien terhadap promosi yang baik dengan promosi kurang baik (100,0\%: 100,0\%). Bila dilihat dari hasil analisis univariat dapat disebabkan karena tingginya presentase pasien yang menyatakan promosi baik $(64,7 \%)$ dan banyaknya pasien yang memiliki asuransi kesehatan $(67,6 \%)$ yang menjalani perawatan di instalasi rawat inap ambun pagi RSUP Dr. M. Djamil Padang. Hal ini yang menjadi penyebab adanya presentase yang sama loyalitas pasien terhadap promosi yang baik dengan promosi kurang baik. 
Tinggi presentase pasien yang menyatakan promosi baik. Ini dapat mempengaruhi rasa loyalitas pasien, keadaan ini dibuktikan pada hasil uji bivariat dimana pasien yang menyatakan promosi baik kesemuanya $(100,0 \%)$ memiliki rasa loyalitas. Asuransi kesehatan juga dapat mempengaruhi rasa loyalitas pasien bila dihubungkan dengan promosi karena asuransi kesehatan merupakan salah satu usaha dalam mempromosikan jasa pelayanan kesehatan rumah sakit. Banyaknya pasien yang memiliki asuransi kesehatan yang menjalani perawatan di instalasi rawat inap ambun pagi. Ini berarti salah satu usaha instalasi rawat inap ambun pagi untuk mempromosikan jasa pelayanan yang ada sudah cukup berhasil dalam menarik minat konsumen yang memiliki asuransi kesehatan. Adanya hubungan signifikan antara promosi dengan loyalitas pasien, dengan nilai $p$ value $0,001(<0,05)$. Bila dilihat dari jawaban responden terhadap kuesioner penelitian, keadaan ini dapat disebabkan karena promosi yang dilakukan oleh instalasi rawat inap ambun pagi sudah cukup jelas dan mudah didapat, baik dari media cetak maupun elektronik $(63,2 \%)$, perawat juga sudah menginformasikan dengan jelas tentang jenis pelayanan yang ada $(55,9 \%)$, alur pelayanan $(63,2 \%)$, tata tertib yang belaku di instalasi rawat inap ambun pagi $(61,7 \%)$ serta baik dan buruknya dari efek tindakan yang akan dilakukan (61,7\%). Adanya informasi yang jelas merupakan sifat dari promosi yang baik. Informasi yang diberikan akan menambah pengetahuan dan membuka cakrawala masyarakat tentang jasa pelayanan yang ada sehingga masyarakat menjadi percaya dan mempunyai keinginan untuk menggunakan jasa pelayanan yang dipromosikan. Hal ini yang menjadikan adanya hubungan signifikan antara promosi dengan loyalitas pasien.

Pada hasil analisis univariat juga dapat dilihat bahwa lebih dari separuh $(64,7 \%)$ pasien yang menjalani perawatan memilki rasa loyalitas yang tinggi terhadap instalasi rawat inap ambun pagi. Hasil ini merupakan keuntungan bagi instalasi rawat inap ambun pagi dalam hal mempromosikan, karena pasien yang loyal dapat dijadikan media untuk mempromosikan jasa pelayanan yang ada kepada pihak lain. Loyalitas pasien yang tinggi terhadap rumah sakit selain dapat memberikan keuntungan, juga dapat menekan angka pengeluaran rumah sakit dalam hal mempromosikan jasa pelayanan yang ada. Ini berarti pasien yang loyal merupakan aset yang baik bagi rumah sakit untuk mempromosikan jasa pelayanan rumah sakit kepada pihak lain.

Pada hasil analisis bivariat didapatkan presentase loyalitas pasien lebih tinggi pada pasien yang menyatakan orang profesional $(100,0 \%)$ dibandingkan dengan pasien yang menyatakan orang kurang profesional $(7,7 \%)$. Hasil uji statistik menunjukan nilai $p$ value $0,001(<0,05)$ maka dapat disimpulkan ada hubungan yang signifikan antara orang dengan loyalitas pasien terhadap instalasi rawat inap ambun pagi RSUP. Dr. M. Djamil Padang.

Hasil penelitian ini sama dengan penelitian yang dilakukan oleh Indriani (2008), yang 
mendapatkan presentase loyalitas pasien lebih tinggi pada pasien menyatakan orang profesional, selain itu juga mendapatkan adanya hubungan signifikan antara orang dengan loyalitas pasien. Sedangkan hasil penelitian yang dilakukan Lita (1999), menemukan bahwa orang yang profesional merupakan faktor yang paling dipertimbangkan oleh konsumen dalam memilih rumah sakit. Pada penelitian ini didapatkan tingginya presentase loyalitas pasien pada orang profesional, bila dilihat dari hasil analisis univariat didapatkan lebih dari separuh $(61,8 \%)$ pasien menyatakan orang profesional dan lebih dari separuh $(64,7 \%)$ pasien loyal terhadap instalasi rawat inap ambun pagi. Dari kedua hasil analisis univariat ini dapat dilihat bahwa presentase pasien yang menyatakan orang profesional dengan pasien yang loyal memiliki presentase yang hampir sama sehingga pada hasil analisis bivariat didapatkan presentase pasien yang loyal lebih tinggi pada orang profesional $(100,0 \%)$ dibandingkan dengan orang kurang profesional (7,7\%). Pada hasil penelitian ini juga didapatkan nilai $p$ value $0,001 \quad(<0,05)$ yang menunjukan adanya hubungan signifikan antara orang dengan loyalitas pasien. Adanya hubungan signifikan antara orang dengan loyalitas pasien. Bila dilihat dari hasil jawaban responden terhadap kuesioner penelitian. Hal ini dapat disebabkan karena perawat di instalasi rawat inap ambun pagi memiliki perilaku ramah dan sopan $(57,3 \%)$, selalu berpenampilan besih dan rapi (55,9\%), merespons dengan baik setiap pasien dan keluarga pasien memerlukan bantuan perawatan $(55,9 \%)$, selalu memberikan motivasi dan dorongan agar pasien memiliki keyakinan untuk sembuh dari penyakit $(54,4 \%)$ dan perawat juga mampu menjaga kerahasiaan penyakit pasien dari orang lain $(58,8 \%)$. Instalasi rawat inap ambun pagi dalam mengembangan orang profesional selalu mengikut sertakan sumber daya manusia yang ada pada pelatihan, seminar dan desiminasi ilmu. Tujuan dari kegiatan ini agar sumber daya manusia di instalasi rawat inap ambun pagi bisa menambah pengetahuan dan keterampilan sesuai dengan kemajuan ilmu pengetahuan yang ada sehingga pada akhirnya dapat meningkatkan kualitas pelayanan, mengingat sumberdaya yang sangat berperan dalam meningkatkan kualitas pelayanan dirumah sakit adalah perawat, selain itu keberhasilan kualitas pelayanan kesehatan juga dipengaruhi oleh partisipasi perawat dalam memberikan pelayanan keperawatan yang berkualitas kepada pasien. Ini berarti pelayanan keperawatan merupakan bagian terpenting dari pelayanan kesehatan rumah sakit.

Pada hasil analisis bivariat didapatkan presentase loyalitas pasien lebih tinggi pada pasien yang menyatakan proses baik $(100,0 \%)$ dibandingkan dengan pasien yang menyatakan proses kurang baik (4,0\%). Hasil uji statistik menunjukan nilai $p$ value $0,001(<0,05)$ maka dapat disimpulkan ada hubungan yang signifikan antara proses dari bauran pemasaran jasa pelayanan keperawatan dengan loyalitas pasien terhadap instalasi rawat inap ambun pagi RSUP. Dr. M. Djamil Padang. Hasil penelitian ini sama dengan hasil penelitian yang dilakukan oleh Indriani (2008), 
mendapatkan presentase loyalitas pasien lebih tinggi pada proses yang baik, selain itu juga mendapatkan adanya hubungan signifikan antara proses dengan loyalitas pasien. Hasil penelitian yang dilakukan oleh Lita (1999), menemukan bahwa proses merupakan faktor yang juga menjadi perhatian pasien dalam memilih rumah sakit.

Tingginya presentase loyalitas pasien terhadap proses yang baik $(100,0 \%)$ dibandingkan dengan loyalitas pasien terhadap proses kurang baik (4,0\%). Hal ini bila ditinjau dari analisis statistik juga dapat dipengaruhi dari hasil analisis univariat. Didapatkan lebih dari separuh $(63,2 \%)$ pasien menyatakan proses adalah baik dan lebih dari separuh $(64,7 \%)$ pasien loyal terhadap instalasi rawat inap ambun pagi. Hal inilah secara statistik yang menyebabkan pasien menjadi loyal pada proses yang baik, karena presentase antara process baik dengan loyalitas pasien tidak jauh berbeda $(63,2 \%$ : 64,7\%). Pada penelitian ini juga menemukan adanya hubungan signifikan antara proses yang baik dengan loyalitas pasien, dengan nilai $p$ value $0,001(<0,05)$. Bila dilihat dari jawaban responden terhadap kuesioner penelitian maka keadaan ini dapat disebabkan karena kebaikan dan citra pelayanan yang dimiliki instalasi rawat inap ambun pagi sudah baik $(61,8 \%)$, perawat di instalasi rawat inap ambun pagi selalu melakukan kontrak waktu dengan pasien maupun keluarga pasien sebelum melakukan tindakan (54,4\%), perawat juga melakukan tindakan sesuai dengan waktu atau jadwal yang telah ditentukan (64,7\%) sehingga pasien tidak menunggu lebih lama untuk mendapatkan tindakan dan pelayanan, selain itu perawat melakukan perawatan sesuai dengan keluhan pasien (64,7\%) dan perawat juga menjelaskan status kesehatan pasien setelah melakukan tindakan $(61,8 \%)$. Adanya kontrak waktu dari perawat kepada pasien dan tepatnya jadwal perawat dalam melakukan tindakan. Hal ini membuat proses dalam pelayanan keperawatan tidak berbelit-belit dan pasien akan merasakan senang karena pasien tidak menunggu lama dan banyak menghabiskan waktu dalam mendapatkan pelayanan keperawatan, karena pelayanan yang berbelit-belit dan menghabiskan banyak waktu tanpa ada tindakan sering membuat pasien beralih kepada rumah sakit pesaing.

Pada hasil analisis bivariat didapatkan presentase loyalitas pasien lebih tinggi pada pasien yang menyatakan bukti fisik baik $(100,0 \%)$ dibandingkan dengan pasien yang menyatakan bukti fisik kurang baik (7,7\%). Hasil uji statistik menunjukan nilai $p$ value $0,001(<0,05)$ maka dapat disimpulkan ada hubungan yang signifikan antara bukti fisik dengan loyalitas pasien terhadap instalasi rawat inap ambun pagi RSUP. Dr. M. Djamil Padang. Hasil penelitian ini sama dengan penelitian yang dilakukan oleh Ika (2009), didapatkan adanya hubungan signifikan antara bukti fisik dengan loyalitas pasien. Lebih lanjut penelitian yang dilakukan oleh Ika (2009), juga menemukan bahwa bukti fisik merupakan salah satu faktor yang mempengaruhi persepsi pasien terhadap pelayanan rumah sakit. Sedangkan penelitian yang dilakukan oleh Lita (1999), mendapatkan bukti fisik merupakan 
salah satu faktor yang dipertimbangkan oleh pasien dalam memilih rumah sakit.

Tingginya presentase loyalitas pasien terhadap bukti fisik yang baik (100,0\%) dibandingkan dengan bukti fisik yang kurang baik (7,7\%). Hal ini bila dilihat dari analisis statistik juga dapat dipengaruhi dari hasil analisis uji univariat, karena lebih dari separuh bukti fisik di instalasi rawat inap ambun pagi adalah baik $(61,8 \%)$ dan lebih dari separuh $(64,7 \%)$ pasien loyal terhadap instalasi rawat inap ambun pagi. Adanya presentase yang hampir sama antara bukti fisik yang baik dengan loyalitas pasien $(61,8 \%$ : 64,7\%), maka hal inilah yang mempengaruhi dari hasil analisis uji bivariat sehingga ditemukan tingginya presentasi pasien yang menyatakan bukti fisik yang baik menjadi loyal terhadap instalasi rawat inap ambun pagi.

Pada hasil penelitian ini juga ditemukan nilai $p$ value $0,001 \quad(<0,05)$ yang berarti adanya hubungan signifikan antara bukti fisik dengan loyalitas pasien. Adanya hubungan signifikan ini bila dilihat dari hasil jawaban respoden terhadap kuesioner penelitian. Ini menandakan bahwa instalasi rawat inap ambun pagi memiliki interior ruangan yang indah dan menarik $(63,2 \%)$, peralatan yang memadai untuk melakukan tindakan $(58,8 \%)$, ruangan yang nyaman dan bersih $(50,0 \%)$ serta perawat selalu menjelaskan pada setiap pasien baru masuk tentang denah ruangan seperti letak kamar mandi, ruangan perawatan dan lain-lain $(61,7 \%)$. Instalasi rawat inap ambun pagi RSUP Dr. M. Djamil Padang dalam memberikan kenyamanan kepada pasien dan keluarga pasien yang sedang menjalani perawatan. Bila ditinjau dari bukti fisik yang dimiliki maka instalasi rawat inap ambun pagi sebagai penyedia pelayanan dengan ruangan rawatan kelas, VIP dan super VIP tentunya memiliki bukti fisik yang baik jika dibandingkan dengan rungan perawatan lainnya yang ada di RSUP Dr. M. Djamil Padang.

Bukti fisik yang dimiliki oleh instalasi rawat inap ambun pagi cukup memberikan kenyaman dan keamanan kepada pasien dan keluarga pasien. Ruangan tunggu yang bersih dengan tata letak yang baik serta pencahayaan yang cukup. Setiap ruangan rawatan memiliki kamar mandi, selain itu juga dilengkapi dengan TV, AC dan lain - lain, khususnya untuk ruangan VIP dan super VIP adanya tempat tidur khusus bagi keluarga yang menemani pasien. Adanya bukti fisik yang baik dengan dilengkapi sarana dan prasarana pendukung yang lengkap serta tempat strategis merupakan keuntungan bagi instalasi rawat inap ambun pagi dalam menarik minat konsumen. Tingginya loyalitas pasien terhadap instalasi rawat inap ambun pagi hendaknya harus didukung dengan bukti fisik yang baik karena antara tempat dan bukti fisik harus memiliki keseimbangan dalam menciptakan loyalitas pasien.

Hasil analisis multivariat dengan menggunakan uji regresi logistik menunjukkan bahwa variabel bauran pemasaran jasa pelayanan keperawatan berhubungan signifikan dengan loyalitas pasien. Hubungan bersama - sama dari variabel bauran pemasaran jasa pelayanan keperawatan terhadap loyalitas pasien terlihat pada variabel orang dan asuransi kesehatan. Variabel asuransi kesehatan merupakan sebagai variabel 
confounding pada penelitian ini. Pada analisis multivariat didapatkan variabel orang memiliki nilai $P$ $=0,998$ dan $\operatorname{Exp} B=3,495$. Ini berarti instalasi rawat inap ambun pagi memiliki orang profesional sebanyak 3,495 dalam meningkatkan loyalitas pasien terhadap instalasi rawat inap ambun pagi bila dibandingkan dengan orang tidak profesional. Untuk analisis persamaan regresi didapatkan variabel orang dengan nilai $\beta=19,672$ ini berarti orang yang paling dominan berpengaruh terhadap loyalitas pasien. Loyalitas pasien terhadap instalasi rawat inap ambun pagi selain dipengaruhi oleh orang propesional juga dikontrol dengan asuransi kesehatan yang dimiliki oleh pasien. Hal ini disebabkan asuransi kesehatan memiliki nilai Exp B dibawah nilai orang yaitu sebesar 2,555. Ini berarti loyalitas pasien terhadap instalasi rawat inap ambun pagi sebagian besar tidak hanya dipengaruhi oleh orang profesional tetapi juga dipengaruhi oleh asuransi kesehatan yang dimiliki pasien.

\section{SIMPULAN}

Tingginya pengaruh orang profesional terhadap loyalitas pasien di instalasi rawat inap ambun pagi. Hal ini dapat disebabkan karena sumber daya manusia, khususnya perawat yang ada di instalasi rawat inap ambun pagi memang memiliki keterampilan dan pengetahuan yang baik dalam memberikan asuhan keperawatan. Keadaan ini dapat dilihat pada hasil analisis bivariat, dimana adanya hubungan signifikan antara orang dengan loyalitas pasien, yang mana hasil ini menunjukan bahwa perawat di instalasi rawat inap selalu bersikap ramah dan sopan, meminta persetujuan pasien sebelum melakukan tindakan, merespons dengan baik setiap pasien dan keluarga pasien membutuhkan bantuan dan dapat menjaga kerahasian penyakit pasien. Asuransi kesehatan yang merupakan variabel confounding pada penelitian ini namun dapat menjadi variabel yang berhubungan bersama - sama dengan variabel orang dalam mempengaruhi loyalitas pasien terhadap instalasi rawat inap ambun pagi. Ini berarti asuransi kesehatan juga mempunyai pengaruh yang cukup besar terhadap loyalitas pasien. Hasil ini bila dilihat dari analisis statistik juga dapat dipengaruhi dari hasil analisis univariat, dimana analisis univariat mendapatkan lebih dari separuh $(67,6 \%)$ pasien yang menjalani perawatan di instalasi rawat inap ambun pagi memiliki asuransi kesehatan.

Hasil penelitian ini menunjukan bahwa bauran pemasaran jasa pelayanan keperawat berhubungan dengan loyalitas pasien. Ini berarti kurang baiknya bauran pemasaran jasa pelayanan keperawatan juga akan berdampak pada menurunnya rasa loyalitas pasien terhadap pelayanan rumah sakit. Menurunnya loyalitas pasien terhadap rumah sakit akan berdampak pada berkurangnya kunjungan ulang. Penurunan kunjungan ulang akan menyebabkan menurunnya pendapatan rumah sakit. Hal ini bila ditinjau dari aspek manajemen akan mempengaruhi mutu pelayanan rumah sakit karena mutu yang tidak baik akan berimbas pada penghasilan rumah. Mutu pelayanan rumah sakit yang tidak baik menandakan bahwa pelayanan keperawatan juga kurang 
berkualitas karena pelayanan keperawatan merupakan bagian integral dari pelayanan rumah sakit. Jadi disini dapat dilihat bahwa salah satu implikasi dari penelitian ini, bila ditinjau dari aspek manajemen adalah untuk melihat indikator mutu dari pelayanan yang diberikan oleh rumah sakit, khususnya dari sumber daya keperawatan (orang).

\section{DAFTAR PUSTAKA}

Agustiono \& Sumarno, (2011). Analisis pengaruh kualitas pelayanan jasa terhadap kepuasan dan loyalitas pasien rawat inap di RS ST. Elisabeth Semarang. Tesis. Unika Soegijapranata Semarang. Tidak dipublikasikan.

Arikunto, S. (2010). Manajemen penelitian. Jakarta: Reneka Cipta.

Budiarto, E. (2002). Biostatiska untuk kedokteran dan kesehatan masyarakat. Jakarta: EGC.

Boulding, W \& Zaitharal, V. A (2003). A dynamic process model of service quality: from expectation to behavioral intentions. Journal of marketing reseatch. Vol 30. (Diakses 3 Maret 2014).

Brown, Barry, Dacin \& Gunst (2007). Servqual: A Multiple item scale for measuring consumenr perceptions of service quality. Journal of retailing. Vol 64. (Diakses 6 Maret 2014).

Cronin, J \& Steven, A. (2006). Measuring Service Quality: A Reexamination and Extension. Journal of Marketing. Vol 56. (Diakses 3 Maret 2014).

Dahlan, M.S. (2008). Statistik dalam penelitian kesehatan, Seri 2. Jakarta: Sagung Seto.

Dewi (2009). Hubungan kepuasan pasien dengan loyalitas pasien di RSUP Fatmawati Jakarta Selatan. Tesis. Depok: FIK UI. Tidak dipublikasikan.

Depkes RI, (1995). Sistem kesehatan nasional. Jakarta: Depkes RI.

Emzir, (2008). Metodologi penelitian pendidikan: kuantitatif dan kualitatif. Jakarta: PT. Raja Grafindo Persada.

Febriyanti (2013). Hubungan kepuasan pasien dalam pelayanan keperawatan dengan loyalitas pasien di RSUP Dr.M.Djamil. Tesis. Padang. Program Pascasarjana FIK. Unand. Tidak dipublikasikan.

Gerson, R.F. (2002). Mengukur kepuasan pelanggan: Panduan menciptakan pelayanan bermutu. Jakarta: PPM

Griffin (2007). Pelanggan kunci keberhasilan. Jakarta: Mitra Utama

Hartono, B. (2010). Manajemen pemasaran untuk rumah sakit. Jakarta: Rineka Cipta.

Hasan, A. (2013). Marketing dan kasus-kasus pilihan. Jogyakarta: CAPS.
Ika D. (2009). Faktor-faktor persepsi pasien tentang bauran pemasaran jasa terhadap loyalitas pasien. Tesis. Semarang. Pasca Sarjana Universitas Diponegoro.

Indriani C. (2008). Pengaruh implementasi program bauran pemasaran terhadap loyalitas pasien di RSUD Acmad Mochtar Bukit Tinggi. Tesis. Padang. Magister Manajemen Universitas Andalas. Tidak dipublikasikan.

Kotler P. (2005). Manajemen pemasaran. Edisi XI. Peterjemah Benjamin Molan. Jakarta. PT Indeks.

Kuntjara (2007). Analisis faktor yang mempengaruhi minat beli ulang konsumen (Studi Kasus di Rumah Sakit Daerah Istimewa Jogyakarta). Jurnal. Jakarta: universitas Borobudur.

Lita (1999). Faktor-faktor yang dipertimbangkan konsumen dalam memilih RSU di kotamadya Padang. Tesis. Padang IKM. Unand. Tidak dipublikasikan.

Lovelock, CH \& Wright, LK. (2005). Manajemen pemasaran jasa. Peterjemah Agus Widyantoro. Jakarta: PT Indeks.

Lupiyoadi (2008). Marketing dan perilaku konsumen. Bandung: CV Mandor Maju.

Meeton (2006). Strategic market managemen. Edisi 4. Jakarta Gramedia.

Notoatmodjo, (2010). Metodologi penelitian kesehatan. Jakarta: Reneka Cipta.

Nursalam, (2011), Manajemen keperawatan: Aplikasi dalam praktek keperawatan profesional. Jakarta: Salemba Medika.

Nursalam, (2009). Konsep dan penerapan metodologi penelitian ilmu keperawatan. Jakarta: EGC.

Nugroho, (2003). Manajemen mutu pelayanan kesehatan. Air Langga University Press.

Peraturan Menkes RI No. 71 Tahun 2013 tentang Pelayanan Kesehatan Pada Jaminan Kesehatan Nasional.

Putra, S.R. (2012), Panduan riset keperawatan dan penulisan ilmiah. Yogyakarta: D-Medika.

Potter, P.A \& Perry, A.G. (2009). Buku ajar fundamental keperawatan: konsep, proses dan praktik. Edisi 4. Jakarta: EGC.

Pramono (2008). Pemasaran jasa konsep dan implementasi. Jogyakarta: CV Ekonisia.

Priyatno, D (2009). Belajar olah data dengan SPSS 17. Jogyakarta: CV Andi Offset.

Ratih (1999). Faktor - faktor yang dipertimbangkan konsumen dalam memilih rumah sakit di RSAB Harapan Kita. Tesis STIE IPWIJA. Tidak dipublikasikan.

Reingen, P. H \& Walker, A (2004). Cross - Unit compettion for a market charter: The enduring influenceof structure. Journal of marketing. Vol 65. (Diakses 6 Maret 2014).

Riyanto, A. (2011), Aplikasi metodologi penelitian kesehatan, Yogyakarta: Nuha Medika.

Robbins, S.P \& Judge, T.A. (2008). Perilaku Organisasi. Peterjemah Diana Angelica, dkk. Edisi 12. Jakarta: Selemba Empat.

Rose. R.C. \& Kim. L. (2004). Hospital Service Wuality : A. Managerial Challenge. International Journal of Health Care Quality Assurance : Vol. 17. No. 3. Pg. 146. 
Rosmawati (2012). Memenangkan dan memelihara pelanggan. Jakarta: Pustaka Tangga.
Sabri, S \& Hastono, P.S. (2010). Statistik kesehatan. Jakarta: PT. Raja Grafindo Persada. 